\title{
WESTERNIZATION, ASIANIZATION AND AFRICANIZATION THE WORLD BETWEEN 1500 AND 2100
}

\author{
Luca DIACONESCU * \\ University of Craiova, Doctoral School of Sciences, Field of Geography, 13st, Alexandru Ioan Cuza St., \\ 200585, Craiova, Romania, e-mail: diaconesculuca@yahoo.ro
}

Citation: Diaconescu, L. (2020). Westernization, Asianization and Africanization the World Between 1500 and 2100. Revista Română de Geografie Politică, 22(2), 90-99. https://doi.org/10.30892/rrgp.222105-339

\begin{abstract}
Until 1800, China and India were the dominant powers of the world, when they are overtaken by the powers of Western Europe, and after 1900 they will be overtaken by the USA, then by Russia and Japan. Now it is time for the Chinese continent to re-assert itself, and after 2050 India will have a similar path and after the end of the demographic explosion in Africa predicted towards the end of the $21^{\text {st }}$ century, it will also become one of the world's rulers, thus proving that the West is only a tab in the history of the movement of wealth on Earth.
\end{abstract}

Key words: great powers, demographic explosion, domination, evolution, industrialization

$* \quad * \quad * * *$

\section{INTRODUCTION}

The West's goal of maintaining world supremacy tends to be disrupted by two extreme factors, namely the industrialization and overpopulation of its former colonies and subjugated states. The small population of Africa, Latin America and Asia that was a supplier of cheap raw materials and importers of finished products with high commercial addition, now with the demographic explosion is forced to cultivate alone the agriculture necessary to feed the population and to process more and more from the raw material, while the western states are facing demographic decline, the aging of the working population and economic greening policies that lead to the closure of production centers, which are being transferred to the new industrial powers. The former states of the Third World need more and more raw materials giving up their export, and the countries that remain suppliers of these materials redirect their attention, from the West, to these new demographic powers.

The current trade picture shows a change that began slightly in the 1940s and accelerated after 1970, with a dizzying speed after 2010, in which the 
countries of the Asian continent from exporting raw materials become heavy consumers and continents and countries such as Africa, Russia, Australia and Latin America, from loyal customers in the US and Europe, are now exporting to Asia. The rapid development of Japan and South Korea, isolated, overpopulated states (340 inhabitants / $\mathrm{km}^{2}$ and 510 inhabitants / $\mathrm{km}^{2}$ respectively), in unfavorable climatic and geological conditions, are telling what can follow with similar states such as: Vietnam, Philippines, Bangladesh, Pakistan, Ethiopia, Uganda or Egypt, and the current economic boom in China gives hope for economic success for countries such as India or Nigeria.

Looking at the population of the Western world, there will be a growing frustration in terms of the demographic dimension of the global planet (the West had $30 \%$ of the world's population in 1900, 17\% in 2020 and only $13 \%$ forecast for 2100), access to the planet's resources increasingly hampered by the growing need of overpopulated states, in the little manufacturing industry that will be made will work millions of emigrants from the south and east with different religions and customs and who are satisfied with low wages and In lower labor standards, products for sale will be made in Asia or Africa, with more and more of the specifics of the civilization in which they were created and new industrial concentrations will pollute the planet, flooding with residues and newly green states that have just killed industry and increased fines and restrictions for their populations, all for environmental protection.

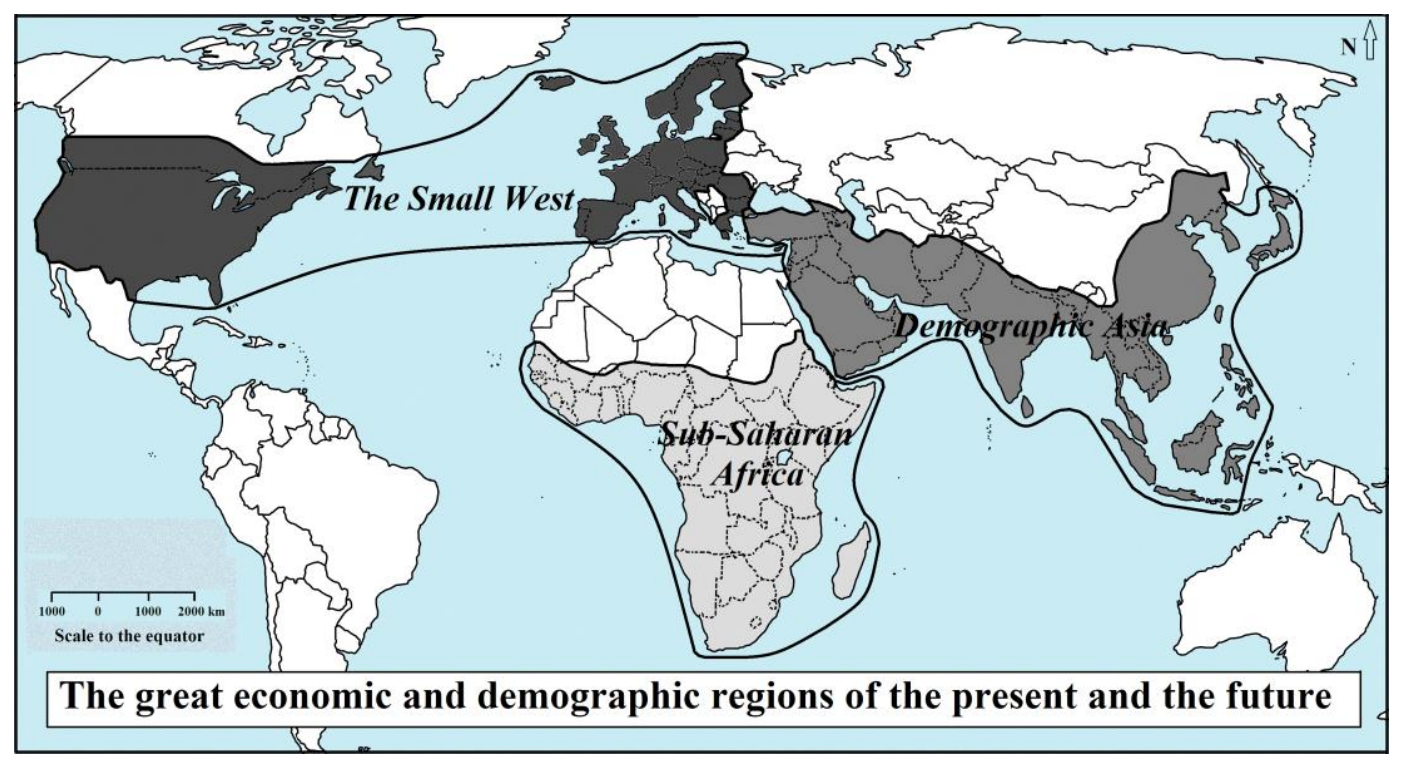

Figure 1. Heavyweights economic planetary between the years 1500 and 2100 Sources: processed after: Atlasul Geografic al Lumii, 2016; Vlad et al., 2010; Der Grosse Marco Polo Weltatlas, 1994

\section{THE SUNRISE IN THE 21ST CENTURY COMES FROM ASIA} The continent is growing demographically and economically annually as much as the whole of spain

The Asian continent has experienced an accumulation of population that no longer allows it to be an exporter of raw materials, and now with the reduction of the population explosion begins to gallop industrialization based on 
a colossal able-bodied population, even importing raw materials from The West expanded, attracting: Russia, Australia, Latin American states and Africa in its sphere of influence (Gaceu, 2007; Mâșu, 2014; Pomeranz, 2009).

As shown in the table below, among the most populous, densely populated or representative European states, the density was 100 inhabitants / $\mathrm{km}^{2}$ in 1900, while the population density in 9 Asian states was only 30 inhabitants / $\mathrm{km}^{2}$ and only 12 inhabitants $\mathrm{km}^{2}$ in Africa, which demonstrates why European countries were forced to develop intensive agriculture and industrialize, importing raw materials from low-density countries. By 2020, although the density in these European countries will increase to 170 inhabitants $/ \mathrm{km}^{2}$, in the Asian countries it will reach 300 inhabitants $/ \mathrm{km}^{2}$, which explains the extent of industrialization and the hunger for raw materials in this continent. But in their turn, the African states, which are growing from 12 to 150 inhabitants $/ \mathrm{km}^{2}$, are starting to raise the issue of industrialization, this process being for the time being only at the planning or dream stage. Until the years 2050 and 2100, the density will increase in the 9 European states with 10 places, reaching 180 inhabitants $/ \mathrm{km}^{2}$, which is quite a lot if we consider that Romania will decrease to less than 70 inhabitants $/ \mathrm{km}^{2}$ and Russia below 8 inhabitants $\mathrm{km}^{2}$, but if we look at the 9 states in Asia, here it increases by a total of 180 inhabitants reaching in 2050 to 400 inhabitants $/ \mathrm{km}^{2}$ and 480 inhabitants $/ \mathrm{km}^{2}$ in 2100 . In these conditions the European states can no longer maintain the title of importing states of raw materials and exporting goods to the Asian states that will become the top of production in a situation of forced and maximum need (from now on, India already has 460 inhabitants $/ \mathrm{km}^{2}$ and China $150 \mathrm{~km}^{2}$ while the USA only 35 inhabitants $/ \mathrm{km}^{2}$ ). Although Asia is the star of industrialization at the beginning of the 21 st century, it seems that towards its end, African states are growing from just 12 inhabitants $/ \mathrm{km}^{2}$ as they were when they represented only a few European power colonies, to over 500 inhabitants $/ \mathrm{km}^{2}$, the question inevitably arises as to whether it will not represent the new demographic-economic Asia, but this aspect will be dealt with in the next chapter.

Table 1. Comparison between demographic evolution and population density of some states in Europe, Asia and Africa

Source: Worldometers, 2020; Ilieş and Staşac, 2000; Unsere Welt, 1996

\begin{tabular}{|c|c|c|c|}
\hline 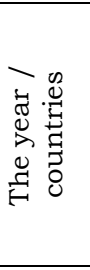 & $\begin{array}{c}\text { European states } \\
\text { Germany, Italy, Great Britain, } \\
\text { France, Greece, Holland, } \\
\text { Switzerland, Austria, Portugal, (all } \\
\text { without colonies) } \\
1,838,000 \mathrm{~km}^{2} \\
\text { million inhabitants (inhabitants } \\
\text { per } \mathrm{km}^{2} \text { ) } \\
\end{array}$ & $\begin{array}{c}\text { Asian states } \\
\text { South Korea, } \\
\text { Philippines, Vietnam, } \\
\text { Bangladesh, Sri Lanka, } \\
\text { Pakistan, Iraq, United } \\
\text { Arab Emirates, Kuwait } \\
2,362,000 \mathrm{~km}^{2}\end{array}$ & $\begin{array}{c}\text { African states } \\
\text { Uganda, Nigeria, } \\
\text { Rwanda, Burundi, } \\
\text { Malawi, Ethiopia, } \\
\text { Ghana, Ivory Coast, } \\
\text { Senegal } \\
\text { 3,193,000 km² }\end{array}$ \\
\hline 1900 & $190 \quad(100)$ & $(30)$ & $(12)$ \\
\hline 2020 & $313 \quad(170)$ & (300) & $(150)$ \\
\hline 2050 & $\sim 331 \quad(180) \sim$ & $\sim 942 \quad(400) \sim$ & $\sim 917 \quad(290) \sim$ \\
\hline 2100 & $\sim 329 \quad(180) \sim$ & $\begin{array}{ll}1.140 & (480) \sim\end{array}$ & $\sim \mathbf{1 . 7 2 0} \quad(540) \sim$ \\
\hline
\end{tabular}

Because $60 \%$ of the territory of Asia is inaccessible to large-scale humanization (Central and North Asia, the western half of China and the deserts of Arab, Lut and Thar), it makes the population density on this continent increase to 250 inhabitants $/ \mathrm{km}^{2}$, so explaining the space crisis it faces and the 
need for its member states to exploit the waters, agricultural lands, forests and subsoil resources of other less populated states (Ianoș and Iacob, 1989; Findlay and O'Rourke, 2009; Popa, 2004; Der Grosse Marco Polo Weltatlas, 1994; Grand Atlas International Sequoia, 1961). The expansion of Asian influence in the world seems premeditated if we look back at the historical evolution, so the economic boom of more and more states is achieved after a break of only 200 years. Between the years 0 and 1800 China and India represented the largest economic powers in the world, being overtaken after 1800 by Western Europe, where the industrial revolution occurs and thus growing economically colonizes and subjugates most of the world. After 1900, the two heavyweights Asians, are also economically surpassed by the USA (In 1800, the USA surpasses India economically, and in 1900 it will also surpass China). Also in Asia were the great empires: Persian, Arab, Ottoman or Mongol, which in turn invaded parts of Europe when the current US territory was not even discovered. The current extension of Asia's power over partially or fully European states such as Russia, Turkey or Italy is nothing new if we refer only to recent history. Like an iceberg that sits only $20 \%$ above the water, Europe with $20 \%$ of the surface of Eurasia began to dominate and sink the continent of Asia only after 1500 and defeated it after 1800, which followed representing a sheet of history that seems to be the end (Baten, 2016; Suciu et al., 2010; Allen, 2011; Săgeată, 2008; Hlihor, 2001).

Japan is for Asia a kind of economic and historical Britain for Europe, South Korea resembles the Netherlands, China a kind of Germany, Vietnam with Poland, India a France and Italy, the Persian Gulf states a kind of Norway, Turkey a kind of Spain, Thailand a kind of Romania and so on. Thus we must get used to the idea that the power of the small states as a surface and population of Europe will be reduced in influence and the Asian states will replace them, but on a scale of 4-6 times larger.

It was mistakenly considered that if the West developed a strong and welldeveloped economic, commercial, scientific or cultural system, the people of Asia could not copy it. And those in Asia can build specializations, schools, hospitals or highways, skyscrapers, factories and so on, using raw materials, technology and the export of finished products and culture precisely through globalization based on the West (Mazilu, 2008; Hobson, 2004; Allen, 2011; Frank, 1998). This is how state organizations similar to the Western ones appeared, but also big money banks, so the states here were seen from simple components in a world owned exclusively by the West, in the main actors of their own assemblies where now also European states, America, Africa or Oceania aspires, emphasizing more and more planetary Asianization.

The Asian population explosion is coming to an end, on a continent overpopulated and facing a severe space crisis and very eager to assert itself, with model states to follow from the most diverse and successes that defy the laws of the economy such as: Japan's economic boom since the late twentieth century, with mountainous and volcanic islands, earthquakes or hurricanes, lacking resources and isolated being in the vicinity of hostile China, the USSR and North Korea; Newly developed China, with an area of continental size and colossal population twice as much as the whole of Europe; Taiwan with grave mountainous relief; destructive desert climate such as the United Arab Emirates; territory with blocked land borders such as South Korea or states that are too small in size between so many giants such as Singapore, Bahrain or Brunei. Examples to follow exist and new emerging economies seem to copy them quickly. 
If we look at things as they seem to be unfolding today, we could see over the years: the Philippines as the new Japan, Vietnam the new South Korea, Malaysia the new Thailand, Sri Lanka the new Taiwan, Iran the new Saudi Arabia, Iraq the new Kuwait and maybe most amazingly, India becoming the new China. The foundations for the arrival of the continent of Asia among the prosperous areas of the world have already been laid, there is a large population able to work, educated, with access to high technology, concentrated in megacities that are connected by highways and modern or equipped trains, with some of the largest ports or airports on Earth, as well as a growing culture of using finance, sales or domination. Although Europe developed high Western society in 5 centuries and Anglo-Saxon America in just 2, in the last half century the transfer of technology, information and education to Asia has been colossal, forcing tens of millions of workers to work in multinational factories, and specialize in this, as well as the development of the necessary services for these workers with stable incomes. That is why the Asian economic boom with a growth of over $5 \%$ per year should not surprise us.

The Asian continent has a number of at least 15 urban agglomerations that together with the periphery exceed the population of Romania, over 30 cities that exceed the population of Hungary, Greece, Belgium, Austria, Switzerland, Sweden, Portugal or the Czech Republic and over 55 cities with a population total in excess of the population of countries such as Denmark, Norway or Finland. In other words, the total population of the state capitals: Italy, Spain, Germany, Switzerland, Austria, Norway, Finland and Denmark together accumulate a population similar or lower to the population of the state capital: China, India, Japan, Korea South, Indonesia, Philippines, Bangladesh or Thailand. We can imagine the magnitude of the development that will be felt in Asia. Just as good products once launched on the market spread like wildfire and were wanted by almost everyone (as was the case with cars, TVs, computers, phones and so on), so consumer goods are making waves in the Asian market forcing the industry to produce at an ever-accelerating pace. "Just as the economic miracle succeeded in Japan, why can't: South Korea, Singapore, Taiwan or Hong Kong?", the inhabitants of these countries asked themselves in the years 1970-2000, and they succeeded. It was the turn of the inhabitants of: China, Thailand, Malaysia, Brunei, Saudi Arabia, Kuwait, Turkey, the United Arab Emirates, Oman or Bahrain in the years 2000-2020, starting to ask this question now the inhabitants of states such as: India, Pakistan, Vietnam, Philippines, Iran, Kazakhstan, Jordan, Sri Lanka, Bangladesh or Indonesia. Pandora's box has opened and progress is in the minds of growing masses of people ready to work hard to get it.

\section{Given the historical evolution of the movement of power in the world, the question arises "Why can't africa follow the economic boom in Asia?"}

An analysis of the evolution of world powers is welcome, which will make us reflect more clearly on the ever-changing and unpredictable geopolitics found in recent history, so we can understand, accept more easily and predict the possible trajectories that humanity will have in the next period, without considering the picture of the current world as crystallized and impossible to change.

The Italian powers Genoa and Venice were the economic and commercial poles of Europe and the Mediterranean, dominating the world economy known between 1000 and 1500, convinced that there can be no real danger in the 
emergence of other powers especially if it was the arid Iberian Peninsula. But the transfer of wealth was made and Spain and Portugal managed after 1492 to dominate the global influence, exceeding all expectations. They came to have large parts of southern and northern Italy, the Netherlands, Belgium, Luxembourg and present-day parts of France and Germany as well as large areas of the Earth, reaching two empires that accumulated an area almost three times larger than Europe. Only certain momentary opportunities made Spain or Portugal not interested in conquering the English islands or the whole of French territory, which was quite poor at the time compared to the wealth administered by Madrid and Lisbon. But after the years 1600-1700, France expanded an empire that surpassed that of the two powers, and Britain brought the surprise, building the largest empire in world history. With weak economies compared to Spain and Portugal, the new empires find it difficult to set out, conquering only unproductive territories that initially consist of deserted areas of the northern half of North America and the African coast, while the riches of the Incas, Mayans or Indians they end up in the hands of the Iberian powers, which, however, stubbornly consider themselves secured as world superpowers for extended periods, hoping that history will be lenient.

The mistake of the idea that the present will be eternal is repeated again, and France and England who held the USA today, much of Africa and two-thirds of Asia, defy any possible emergence of a great power in the east, especially the Netherlands, the German or Italian states were divided into many self-governing provinces, and the Austro-Hungarian Empire was dominated by two very different peoples and consisted of at least 6 other equally diverse peoples. The possibility of these parts of the world becoming superpowers, without territories held outside Europe, or with insignificant territories, was minimal. The Netherlands was the first star to shine, with a small population, a territory often flooded and restricted between great powers, only with the territory of Indonesia more extensive between the colonies and removed from the territories of Brazil, India or South Africa by other European powers, through trade between the French, English, Spanish, and Portuguese colonies, it became by surprise the largest naval power shattering the theory that a country with claims to superpower should have its own overseas territories.

Another surprise comes at the beginning of the twentieth century, when the eastern states, with no substantial access to the seas and oceans, without a developed maritime fleet and with too few colonies owned, do what we could say the Central European miracle. Germany with few colonies in Africa and AustriaHungary, which has never left Europe territorially, is economically overtaking the West, and this is how the space crisis of mega-powers in Europe is created. The Atlantic powers bring the world's wealth to Europe, while the German states, through developed industry, manage to transfer it to the east. At the same time, a so-called "United States of Europe on the New Earth", appears in North America, founded by the massive migration of Europeans fed up with the long wars at home. Europe had become too small for the powers that divided it. They quickly accepted the new country United States of America and the tension between the Europeans makes the world's attention neglected, and after the US, weak demographically and formed of little humanized lands, appears as a new power attached as an extension of Europe, in the same time in the extremity of Asia far from the great civilizations, the yellow men from the inhospitable Japanese archipelago become ready to take part in the division of the world. 
After the two great world conflagrations (First and Second World War) caused by the surprise of new powers (Japan, Austria-Hungary, Germany and Italy), they managed to capture Europe, large parts of Africa, East Asia, Southeast and southern and northern Oceania, colonizing even the mega-powers France and the Netherlands, and almost kneeling England, after the end of the wars remain victorious two states on the periphery of Europe, the US intervening at the end of the war and a new force from the east, Russia, although severely destroyed of war.

Western Europeans had to change theories of education that only colonial empires could dominate the world and give an explanation for the success of the Netherlands, Germany or Austria-Hungary, then they had to give an explanation as to why the US, a non-European state, could be mega-power, and even harder was when they needed an answer to Japan's inexplicable success so linguistically, religiously and culturally different from Europe. After 1945, the emergence of the mega-power of the USSR (Russia) again defied the laws of power, which had an always cold, non-Western territory, with Slavic language and Christian-Orthodox religion and above all, with a system of leadership embodied in communism, very different from the old capitalist system developed over hundreds of years. It developed an empire and influence equal in power and economy with the Western system dominated after 1945 by the United States, being further unexpected proof that the system that existed until then was neither unique nor forever dominant. It took five centuries for Western Europe to dominate the world, only two centuries for the USA, 4 decades for Japan and 3 decades for Russia (USSR). Seemingly invincible in 1980, after only 15 years, Russia becomes far inferior to the United States and begins to outperform itself economically in the next two decades with countries such as Italy or South Korea, often losing competition.

At the end of this half-century in which Russian was the subject of study in many schools around the world, it is beginning to be forgotten by people as if it did not exist, and now it seems natural in the perception of humanity as the European Union that sums it all up the colossal powers of Europe (Italy with Venice and Genoa, Spain, Portugal, France, Great Britain, the Netherlands, Germany or Austria and Hungary) together fail to cope economically, decisively or even culturally with US power even if they hold 200 millions more people. It also began to seem natural in the 2000s for Japan, a small island country isolated from the waters of the Pacific Ocean, to dominate the world high-tech market, holding more economic power than France and Britain combined, also surpassing China 5 times, even if it held only $10 \%$ of the population they. This shows how absurd the geopolitical world we live in is and how society is educated to agree with the situation it finds itself considering the world to be fair, just and eternal in its form at that time.

After all this shift in world wealth and recent history in major change, it still appears as a shock the development of South Korea beyond Spain or Russia, how can Indonesia, Turkey or Saudi Arabia overtake the Netherlands or newly industrialized China how it arrived to compete economically with the whole of the European Union or the USA, recovering so much in just 20 years. Tomorrow's world will naturally see China's global domination as natural, but it will be shocked by the rise of India, which I now look down on as China looked 20 years ago. 
Accepting the shift of power on Earth so far and having some prognosis for the coming decades, we can naturally ask whether the power of the world was in the hands of Italians, Spaniards, French, English, Germans in Europe, then Americans or Russians in Eurasia, the Japanese, now in the possession of the Chinese and probably the Indians in the not too distant future, why Africans, referring to Sub-Saharan Africa-Black, why can't it hold some supremacy in the next decade ? Especially since the population of this region will most likely have $40 \%$ of the world's population over 80 years, when it will have as much as Asia or 7 times as much as Europe.

Currently, the centers of cities such as Johannesburg, Cape Town, Durban, Luanda, Nairobi, Kinshasa, Lagos, Abidjan, Accra or Addis Ababa rise, in some places, to the level of facilities provided by European cities, and grandiose projects in progress or already completed such as: multiple modern railways, gas pipelines in Chad, Cameroon, Sudan or Nigeria, Grand Inga hydropower plants in Congo and the Great Renaissance Dam on the Blue Nile in Ethiopia, highways in Nigeria, Ivory Coast or Ghana, the technological city of Konza near Nairobi, ports in Kenya (Mombassa) or Tanzania (Dar es Salaam), or almost 500 million internet users, 500 million subscribers and 800 million used SIM cards and almost 300 million smartphones, all of which inconceivable for this territory five decades ago, prove it possible. Why can't these oases of wealth or mega-projects cover larger and larger areas of sub-Saharan Africa? This approach to underestimating this world may be a mistake made so many times in history, when it was falsely considered that certain regions are not entitled to become dominant mega-powers like others.

Table 2. Competition between the three economic and demographic mega-regions of the world, by various categories, between 1900 and 2100

Source: processed after: Worldometers, 2020; World Integrated Trade Solution, 2020; Parthasarathi, 2011; Canrong, 2020

\begin{tabular}{|c|c|c|c|c|c|c|c|}
\hline No. & Region & $\begin{array}{c}\text { Approximate } \\
\text { area } \\
\mathrm{Km}^{2}\end{array}$ & $\begin{array}{c}\text { Population } \\
1900 \\
\mathbf{2 0 2 0} \\
2100 \\
\text { (Estimate) } \\
\text { Millions of } \\
\text { inhabitants }\end{array}$ & \begin{tabular}{|c|} 
Urban \\
agglomerations \\
with over 8 \\
million \\
inhabitants \\
$(2020)$
\end{tabular} & \begin{tabular}{|c} 
GDP \\
Nominal \\
between \\
Years $2000-$ \\
2020 \\
Trillions of US \\
Dollars
\end{tabular} & \begin{tabular}{|c} 
GDP \\
Purchasing \\
Power Parity \\
between the \\
years 2000 - \\
2020 \\
Trillions of US \\
Dollars
\end{tabular} & \begin{tabular}{|c} 
Trade \\
(export 2000 - \\
2020) \\
Trillions of US \\
Dollars
\end{tabular} \\
\hline I & $\begin{array}{l}\text { Small West (EU, } \\
\text { UK, Norway, } \\
\text { Switzerland + } \\
\text { Anglo-Saxon } \\
\text { America, without } \\
\text { frozen north) }\end{array}$ & 17 millions & $\begin{array}{l}380 \\
870 \\
950\end{array}$ & 16 & $20-45$ & $20-45$ & $3,9-7,5$ \\
\hline II & $\begin{array}{c}\text { Restricted Asia } \\
\text { (excluding Russia, } \\
\text { Central Asia, } \\
\text { Tibet, Gobi } \\
\text { and New Guinea) }\end{array}$ & 17 millions & $\begin{array}{c}900 \\
\mathbf{4 . 5 0 0} \\
4.500\end{array}$ & 50 & $8-31$ & $16-65$ & $1,4-7,0$ \\
\hline III & $\begin{array}{c}\text { Restricted Africa } \\
\text { (no north with the } \\
\text { Sahara desert) }\end{array}$ & 17 millions & $\begin{array}{c}110 \\
\mathbf{1 . 1 0 0} \\
4.000 \\
\end{array}$ & 7 & $0,4-2$ & $1,1-4,5$ & $0,08-0,4$ \\
\hline
\end{tabular}




\section{CONCLUSIONS}

The seventeenth and nineteenth centuries represented the European demographic boom, the eighteenth and mid-twentieth centuries represented the American population explosion, the twentieth century represented the Asian population boom and the twentieth and twenty-first centuries will be the African population explosion. We are at the end of the Asian population explosion (between 1900 and 2020 the population of Asia has increased 5 times, from 900 to 4,600 million) and in the midst of the African population explosion (between 1900 and 2100, its population will increase 50 times, from 100 million to 5,000 billion). It seems that at the end of the period of population growth, the economic boom appears, as it happens with Europe and America, now with Asia and in the future following the same evolution, it will be Africa's turn.

From any historical point of view, the domination of the West is only a stage of history that is natural to end leaving room for new actors, and the fact that the US depends on the export of finished products from Asia and Europeans looks forward to being part of development programs and New Asian banks (Asian Investment and Infrastructure Bank and New Development Bank), prove how easy it has already been to move from dominator to dominant, Asia being a demographic advantageous continent (5 times more population than the EU, the Great Britain and the US combined) and with 4 of the top 10 world economic powers (after GDP PPP), almost 50\% of world GDP PPP and 30 of the top 38 urban agglomerations with peripherals exceeding 20 million inhabitants (Diaconescu and Lung, 2018).

\section{REFERENCES}

Allen, R.C. (2011). Global Economic History: A very short introduction, OUP Oxford Publishing House, UK.

Baten, J. (2016). A History of the Global: 1500 to the present, Cambridge University Press Publishing House, UK.

Canrong, J. (2020). China. Responsabilitatea unei mari puteri (China. The responsibility of a great power), Editura Corint Books, București.

Diaconescu, L., \& Lung, M. S. (2018). Power of big cities. Revista Română de Geografie Politică, 20(2), 67-74.

Findlay, R., \& O'Rourke, K. (2009). Power and Plenty: trade, war, and the World economy in the second millennium, Princeton University Press Publishing House, USA.

Frank, A.G. (1998). Reorient: Global economy in the Asian age, University of California Press Publishing House, USA.

Gaceu, O. (2007). Asia, Oceania și Australia, Editura Universității din Oradea, Oradea (Romania).

Hlihor, C. (2001). Istorie şi geopolitică în Europa secolului XX (History and geopolitics in twentieth century Europe), Editura RAO, București.

Hobson, J.M. (2004). The Eastern origins of Western civilisation, Cambridge University Press Publishing House, UK.

Ianoș, I., Iacob, G. (1989). Câmpiile Terrei (The plains of the Earth), Editura Albatros, București.

Ilieş, A., \& Staşac, M. (2000). Studiul geografic al populatiei: curs practice (Geographical study of the population). Editura Universității din Oradea.

Mazilu, M.E. (2008). To be or not to be afraid of globalizationin Journal?, Analele Universității din Craiova, Seria Geografie, 11, 87-91.

Mâşu, M.S. (2014). Puterea economică în istoria lumii: 1. De la Marele Rift preistoric la Marele Război din 1914 (Economic Power in World History: 1. From the Prehistoric Great Rift to the Great War of 1914), Editura RAO, București.

Parthasarathi, P. (2011). Why Europe grew rich and Asia did not, Cambridge University Press Publishing House, UK.

Pomeranz, K. (2009). The great divergence: China, Europe, and the making of the modern World economy, Princeton University Press Publishing House, USA. 
Popa, N. (2004). Geografia continentelor. Asia. Caracterizare geografică generală (Geography of continents. Asia. General geographical characterization), Editura Universității de Vest, Timișoara (Romania).

Săgeată, R. (2008). Geopolitică, Editura Universității "Lucian Blaga”, Sibiu (Romania).

Suciu, F.B., Caunic, I., Muntele, I. (2010). Euro-Atlantic democracy confronting a strategic challenge. Revista Română de Geografie Politică, 12(2), 285-296.

Vlad, B.L., Josan, A., Vlasceanu, G. (2010). Active geo-strategic players, geopolitical pivots and the changing balance of power in Eurasia. Revista Română de Geografie Politică, 12(1), 116-125.

*** (2016). Atlasul Geografic al Lumii (The Geographical Atlas of the World), Editura Cartographia, Budapesta.

*** (1994). Der Grosse Marco Polo Weltatlas. Mairs Geographischer Publishing House, Verlag, Stockholm, Sweden.

*** (1961). Grand Atlas International Sequoia. Kartographisches Institut Publishing House, Paris, Bruxelles.

*** (1996). Unsere Welt. Der Atlas fur die ganze Familie. GeoData GmbH Publishing House, Stuttgart, Germany.

*** WORLDOMETERS, real time world statistics: www.worldometers.info, last accessed, February, 2020.

*** World Integrated Trade Solution WITS, https://wits.worldbank.org, last accessed, February, 2020.

Submitted:

May 20, 2020
Revised:

September 24, 2020
Accepted and published online:

November 04, 2020 